\title{
The use of biological activities to monitor the removal of fuel contaminants - perspective for monitoring hydrocarbon contamination: a review
}

Mphekgo P. Maila, Thomas E. Cloete

\section{Contents}

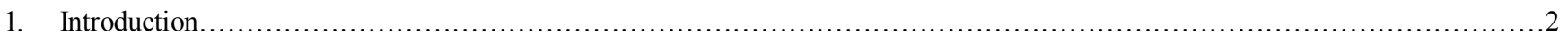

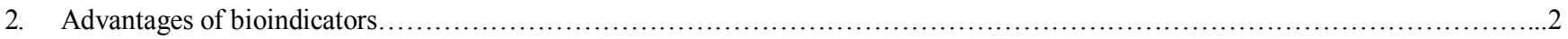

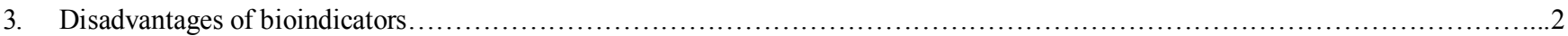

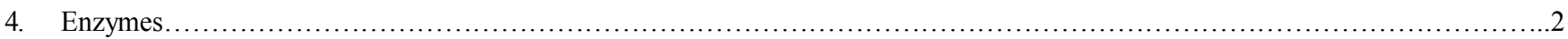

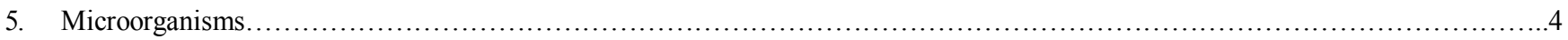

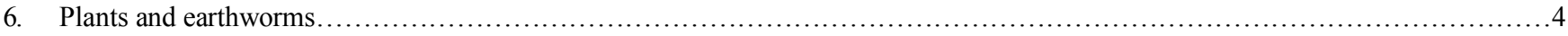

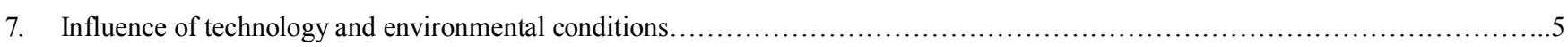

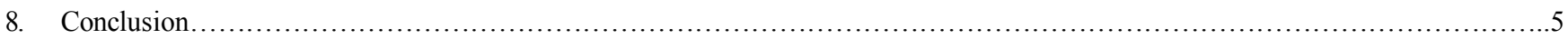

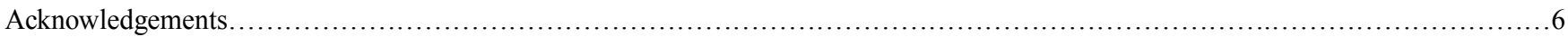

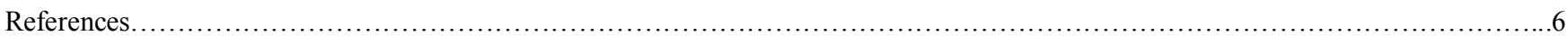




\section{Introduction}

The increasing concern about the cost of soil remediation has necessitated the need to explore not only cost effective technologies but also alternative monitoring tools. The progress of remediation of hydrocarbon-contaminated soil is usually monitored by conventional chemical analytical instruments like GC-MS, which can be expensive. Owing to the cost associated with traditional monitoring tools, focus is now shifting towards using biological activities for monitoring of bioremediation of hydrocarbon-polluted soil. The use of bioindicators to evaluate hazardous chemical waste sites provides a direct, inexpensive and integrated estimate of bioavailabi-lity and contaminant toxicity (Mueller et al., 1991; Wang and Freemark, 1995; Maila and Cloete, 2002).

Many promising approaches using bioindicators as monitoring instruments have been reported (Athey et al., 1989; Siciliano et al., 1997; Dorn et al., 1998; Marwood et al., 1998; Margesin et al., 1999; Maila and Cloete, 2002).

\section{Advantages of bioindicators}

The advantages of bioindicators are

- They can detect both toxicity of parent compounds and toxic metabolites;

- Readily available materials are used in the test;

- The test can be performed ex situ or in situ;

- The test period in most cases is short;

- Uncomplicated methodology is used to assess the extent of pollution reduction.

\section{Disadvantages of bioindicators}

\section{The disadvantages are}

- The inability to distinguish toxicity resulting from parent compound and metabolites;

- Bioindicator response does not always correspond with contaminant concentration;

- Different tests respond differently to individual toxicants;

- Sensitivity depends on the toxicant and soil (i.e. the test can be sensitive to other factors of the soil).

A list of bioindicators that have been tested as potential monitoring tool of hydrocarbon removal (Table 1) shows that these approaches include the use of enzymatic activities, seed germination, earthworm survival and microorganisms or microbial bioluminescence as bioindicators. These biological processes have varying degrees of success as monitoring tools. Reliable bioindicators must give interpretable response curves across a range of environmental parameters (Adema and Henzen, 1989; Hund and Traunspurger, 1994), otherwise environmental effects upon bioindicator response may confound extrapolation meant to depict the bioavail-ability and toxicity of contaminants in soil.

This paper reviews the types of potential bioindicators, including enzymes, seed germination, earthworm survival and microbial bioluminescence, used for monitoring the remediation of soil contaminated with petroleumcompounds.

\section{Enzymes}

Because of their central role in the soil environment, soil enzyme activities are attractive as indicators for monitoring various impacts on soils: soil enzymes are the catalysts of important metabolic process functions including the decomposition of organic inputs and the detoxification of xenobiotics. Besides their use in the case of hydrocarbons, soil biological activities have been used as biological indicators of pollution with heavy metals or pesticides (Bayer et al., 1982; Dick, 1997; Top et al., 1999).

The degradation of hydrocarbons to simple molecules such as water and carbon dioxide involves many chemical reactions in which catalytic proteins are involved. Because of their central role in hydrocarbon degradation, it is not surprising that focus is now shifting towards using themas potential monitoring tools during bioremediation. Enzymes that have been tested for their potential to monitor hydrocarbon removal include soil lipases, dehydrogenases, catalases and ureases (Table 2). However, their use has been confined to laboratory studies. Laboratory-scale studies show great potential for the use of these proteins as bioindicators of hydrocarbon removal. Of the catalytic proteins tested, soil lipases have shown great potential in monitoring bioremediation of hydrocarbon (Margesin et al., 1999). Dehydrogenases, catalases and urease have been found only to be useful for indicating the onset of the biodegradation process, as their activities decline rapidly after the rate of biodegradation has decreased (Frankenberger and Johanson, 1982; Janke et al., 1992; Van der Waarde et al., 1995; Margesin and Schinner, 1997). In addition, the increase in soil dehydrogenase activity in hydrocarbon-contaminated soil has been 
Table 1

Different bio-indicators that were used in monitoring hydrocarbons removal

\begin{tabular}{|c|c|c|c|}
\hline Bioindicator & Pollutant specificity & Sensitivity and range tested & References \\
\hline \multicolumn{4}{|l|}{ Enzymes } \\
\hline Soil lipase & Diesel oil, mineral oil & Sensitive; up to $1 \mathrm{mg} \mathrm{g}^{-1}$ soil & Margesin et al. $(1999,2000)$ \\
\hline Soil dehydrogenase & $\begin{array}{l}\text { Crude oil and refined petroleum } \\
\text { products }\end{array}$ & $\begin{array}{l}\text { Moderately sensitive; } 20-60 \% \text { (w/ } \\
\text { w) oil/dry soil. }\end{array}$ & $\begin{array}{l}\text { Frankenberger and Johanson } \\
\text { (1982) }\end{array}$ \\
\hline Urease and catalase & Mineral oil & $\begin{array}{l}\text { Less sensitive; detectable at high } \\
\text { TPH concentration }\left(5000 \mathrm{mg} \mathrm{kg}^{-1}\right. \\
\text { soil) }\end{array}$ & Margesin et al. (2000) \\
\hline \multicolumn{4}{|l|}{ Seed germination } \\
\hline $\begin{array}{l}\text { Prairie grass (Canada blue grass } \\
\text { and slender wheatgrass) }\end{array}$ & Aromatics (Halogenated) & Sensitive; $13-133 \mu \mathrm{g} \mathrm{kg}^{-1}$ soil & $\begin{array}{l}\text { Wang and Freemark (1995), } \\
\text { Siciliano et al. (1997) }\end{array}$ \\
\hline L. sativum & PAHs & $\begin{array}{l}\text { Moderately sensitive, } \\
50-1000 \mathrm{mg} \mathrm{kg}^{-1} \text { soil }\end{array}$ & Maila and Cloete (2002) \\
\hline Microbial biomass & Oil contaminated soil & Moderately sensitive & Kalender et al. (1994) \\
\hline \multicolumn{4}{|l|}{ Batteries' of bioindicators } \\
\hline $\begin{array}{l}\text { Microbial bioluminescence, } \\
\text { earthworm and seed germination }\end{array}$ & $\begin{array}{l}\text { Creosote, heavy, medium and light } \\
\text { crude oils. }\end{array}$ & $\begin{array}{l}\text { Moderately sensitive. } \\
\text { Earthworm }>\text { seed germination }> \\
\text { bioluminescence } 25-17,400 \mu \mathrm{g} \mathrm{g}^{-1} \\
\text { soil. }\end{array}$ & $\begin{array}{l}\text { Wang and Freemark (1995), } \\
\text { Dorn et al. (1998), Phillips et al. } \\
\text { (2000), Shakir et al. (2002) }\end{array}$ \\
\hline
\end{tabular}

Table 2

Measurements of enzymatic activities in hydrocarbon contaminated soil

\begin{tabular}{llll}
\hline Process & Enzyme & Methodology & References \\
\hline Hydrocarbon mineralization & Soil lipase & Titration & $\begin{array}{l}\text { Pokorna (1964), Schinner et al. } \\
(1996), \text { Margesin et al. (1999), } \\
\text { Stevenson (1959), Frankenberger } \\
\text { and Johanson (1982) }\end{array}$ \\
& Soil dehydrogenases & $\begin{array}{l}\text { Spectrophotometer (color } \\
\text { intensity measurement) }\end{array}$ & Margesin and Schinner (1997) \\
& Catalases & Tritation & Margesin and Schinner (1997) \\
\hline
\end{tabular}

found to be in proportion to the rates of oil application, in which activity increased with increasing loading rates (Frankenberger and Johanson, 1982). Any influence that oils may have on soil dehydrogenase activity is dependent on their chemical composition. In a review, Cole (1983) noted that oxygenation is a common process in pesticide and herbicide metabolism and is an important initial mode of attack when organisms encounter what are often highly lipophilic compounds. However, not much work has been done on this particular process as a potential bioindicator of pollutant removal in soil.

Most enzymatic tests are artificial and refer to the potential activity of soil enzymes. A defined amount of soil is incubated in aqueous environment with a specific substrate and sometimes a buffer (Bitton and Koopman, 1992). The enzyme converts the specific substrate to another compound that can be extracted and quantified, e.g. by spectroscopy. For lipases, tributyrin is used as a substrate that is catalytically converted to butyric acid, which can be extracted and quantified (Table 2). The main advantage of enzymatic tests is that they offer an easy method of measurement, but a disadvantage might be their indirect approach.

Not all enzymes are synthesized by a cell in the same amounts; some enzymes are present in far greater number than others. In bacterial cells, regulation of the amount of enzyme by induction and repression occurs at the gene level, whilst the enzyme activity is regulated through product inhibition, covalent modification and feed back inhibition (Brock and Madigan, 1991). The required amount of hydrocarbons in soil that can induce the necessary enzymes to bring about the metabolism of specific hydrocarbons is not known. However, based on the ATP required to synthesize the proteins of bacterial cells and the 
diffusion, limited by the volume of water surrounding cells, it is estimated that at least about $150 \mathrm{mg}$ substrate $\mathrm{L}^{-1}$ soil water should be present (Sims et al., 1991).

\section{Microorganisms}

The immediate concern of rehabilitation practitioners when assessing the strategy and outcome of bioremediation is the availability and capacity or degradative potential of the autochthonous microbial communities. The use of microorganisms as instruments for monitoring hydrocarbon-contaminated soil is not well established. However, microbial bioluminescence, microbial biomass/counts and soil respiration have been evaluated as potential tools for monitoring of hydrocarbons (Delistraty, 1984; Kandeler et al., 1994; Steinberg et al., 1995; Van Beelen and Doelman, 1997; Phillips et al., 2000).

Microbial bioluminescence involves the activities of electron transport systems, which produce substrates for the production of light. This monitoring tool has been evaluated as a potential bioindicator of a number of organic compounds (Table 3). The employment of bioluminescence is attractive since it more closely reflects toxicity than does the use of chemical analysis (Steinberg et al., 1995). In addition, the application of bioengineering to produce or enhance bioluminescence properties of organisms may lead to new systems for assessing environmental toxicity. The disadvantage of using bioluminescence is the possibility of bacteria adsorbing to soil particles and thereby being filtered out of suspension, resulting in lower luminescence than would correctly represent the level of soil toxicity (Hund and Traunspurger, 1994; Benton et al., 1995; Cook and Wells, 1996; Ringwood et al., 1997). For further information on bioluminescence, the reader is referred to Steinberg et al. (1995).

It is widely assumed that the number of indigenous biodegraders increases with the reduction of hydrocarbons and that the microbial population changes after hydrocarbon pollution. Wünsche et al. (1995) reported that changes in hydrocarbon content in soil resulted in characteristic shifts of the substrate utilization patterns by the microorganisms, and that the altered pattern of substrate utilization corresponded with similar changes in abundance of hydrocarbon-utilizing bacteria and the occurrence of specific bacterial groups in the soils. Increases of hydrocarbon degrading bacteria during bioremediation have been reported elsewhere (Pearce et al., 1995; Margesin et al., 1999). The concern with using microorganisms as bioindicators is that changes in bacterial numbers might be indicative of a stimulated biodegradation process, but they do not necessarily represent an accurate measurement of the actual biodegradation. In addition, the added biodegradative strains (in the bioaugumentation process) are notoriously unreliable in their ability to compete with native microorganisms when released into the natural environment (Van Veen et al., 1997). There are cases, however, where microorganisms have been used with relative success in detecting the removal of hydrocarbons in soil (Steinberg et al., 1995).

Microbial processes have also been used in monitoring pesticide removal from the soil (Top et al., 1999). As the literature shows (see, for example, Martin et al., 1978; Weissenfels et al., 1992, and Margesin et al., 2000), the microbial process used most widely in detecting biotoxicity and biodegradation of contaminants is respiration. This process cannot, however, be reliably used to monitor hydrocarbon removal, as it is difficult to distinguish biological hydrocarbons removal from decomposition of other soil organic compounds present. Microbial respiration in soil is usually evaluated using respirometry and through titration. Phillips et al. (2000) evaluated six soil toxicity tests (including Microtox) to monitor bioremediation of creosote-contaminated soil and found that the test results did not always correlate with contaminant concentrations, nor were the trends indicated by each test consistent for any of the soil types used in the study.

Table 3

The use of bioluminescence to monitor/detect hydrocarbons

\begin{tabular}{|l|l|l|}
\hline Organisms/system & Primary reported compound/class & Reference \\
\hline Photobacterium phosphoreum & Creosote & Phillips et al. (2000) \\
Pseudomonas fluorescens & Naphthalene & King et al. (1990), Heitzer et al. (1994) \\
Photobacterium phosphoreum & Organics & Kaiser and Palabrica (1991) \\
Photobacterium phosphoreum, Vobrio harveyi & Synfuel by-products & Delistraty (1984) \\
\hline
\end{tabular}

\section{Plants and earthworms}

Two methods that are widely used for measuring soil toxicity are seed germination and earthworm survival assays (Green et al., 1988). Other tests used for water have been adapted for soil (Kwan and Dutka, 1992; Quillardet and Hofnung, 1993; Dutka et al., 1995; Cook and Wells, 1996; Ringwood et al., 1997). Seed germination and earthworm survival assays also have the potential to be used as bioindicators of hydrocarbons removal in soil. The sensitivity of earthworms to hydrocarboncontaminated soil has been reported by Shakir et al. (2002). Earthworm survival and seed germination tests are sensitive to changes in soil toxicity during bioremediation of soil contaminated with polycyclic aromatic hydrocarbons (PAHs) or petroleum hydrocarbons (Athey et al., 1989; Dorn et al., 1998; Marwood et al., 1998; Knoke et al., 1999).

Seed germination and earthworm survival tests are useful as bioindicator response endpoints because of their simple 
methodology, their moderate sensitivity to toxicants and their potential for use both in situ and ex situ. The application of these tests as potential bioindicators has, however, been confined to laboratory-scale studies. Maila and Cloete (2002), reported that the level of germination in Lepidium sativum (garden cress) decreased with increasing PAH concentration in artificially contaminated soil, while no germination occurred in historically PAH-polluted industrial soil. In tests during phytoremediation of PAH, the germination level of L. sativum was inhibited during the first weeks, after which germination increased, possibly due to dissipation of PAH fromthe soil.

Bioindicator response to organic pollutants varies in different plant species. Siciliano et al. (1997), reported a 12-fold difference in 2CBA (2-chloro benzoic acid) and 10-fold differences in Aroclor 1260 sensitivity among grass species. According to Cairns (1993), and Chapman (1995), the use of indigenous species (as bioindicators) will increase the relevance and reliability of bioindicator testing. When Dorn et al. (1998) evaluated the sensitivity of different bioindicators to oil-contaminated soil, earthworms were 1.4-14 times more sensitive than microbial bioluminescence and 1.3-477 times more sensitive than seed germination to the oily soils. Overviews of the use of plant (vascular macrophyte) phytotoxicity testing and its role in environmental monitoring and assessment are to be found elsewhere (see Wang and Freemark, 1995).

Phillips et al. (2000) reported that, although total petroleum hydrocarbons (TPHs) in soil was reduced following treatment, earthworm and seed germination tests still showed an increase in toxicity, an indication that toxic intermediary metabolites may have formed during biodegradation.

\section{Influence of technology and environmental conditions}

The use of biological activity to evaluate hazardous chemical waste sites provides a direct, inexpensive, and integrated estimate of contaminant toxicity (Mueller et al., 1991; Wang and Freemark, 1995). However, it appears that apart from the pollutants, remediation technologies do have an effect on the bioindicator response (Siciliano et al., 1997; Margesin et al., 1999). For example, biostimulation of hydrocarbon contaminated site had an effect on the activity of the extracellular enzyme lipase (Margesin et al., 1999). The presence of inorganics ( $\mathrm{N}$ and $\mathrm{P}$ ) accelerated the activity of the extracellular enzyme lipase. As Belkin et al. (1994), Hund and Traunspurger (1994) and Siciliano et al. (1997) have shown, biological treatments may have a negative effect on bioindicator responses. The last-mentioned authors reported that the effect of soil type on bioindicator response varies in different plants. The effect on the response of Canada blue grass to 2-chlorobenzoic acid (2CBA) was significant, but no significant difference was observed in the germination response of wheat grass. Differences in one of the soil components will alter the toxicological hazard associated with a contaminated site. Implicit in this measurement of bioavailability and toxicity is the independence of bioindicator response to other organisms in the ecosystem. It is well documented that many organisms produce toxins which minimize competition (Curl and Truelove, 1986). It is thus important to understand the effect of the treatment technology and environmental conditions on bioindicator response.

Soil factors such as organic matter, pore space and $\mathrm{pH}$ play an important role in pollutant bioavailability in soil (DeVliegher and Verstraete, 1996). It is estimated that about one-third of the initial contamination is lost through abiotic phenomena such as volatilizaton, sorption processes and chemical transformation (Margesin et al., 1999). Bioavailability, degradation and toxicity of soil contaminants are all influenced by sorption, which is influenced by time, and the physicochemical properties of individual soils (Manilal and Alexander, 1991; Weissenfels et al., 1992; Erickson et al., 1993, Loehr and Webster, 1996; White and Alexander, 1996).

Effective bioindicators require a rapid and reliable methodology that characterizes the extent of contamination, minimizes worker exposure and reduces artifacts induced by sampling the soil. Bioindicators integrate measurement of contaminant bioavailability and toxicity.

\section{Conclusion}

A number of methods can be used to assess the extent of hydrocarbon contamination in soil. However, the uniqueness or heterogeneity of the soil, formation of toxic metabolites and the influence of technology contribute towards 'poor' bioindicator response of the different biological activities. Chemical and toxicity data do not always corroborate one another, and the results of each toxicity test in a battery do not always agree, due to each soil being unique in the response that it induces and each toxicity test unique in its ability to detect different contaminant levels in different soils.

There is, therefore, a need to understand the influence of these factors on bioindicator response. For enzymes to be successfully used as monitoring tools during bioremediation of hydrocarbons, enzyme induction by the pollutant (hydrocarbons) as well as other soil compounds must be investigated. Not all inducers and co-repressors are substrates or end products of the enzyme involved (Brock and Madigan, 1991). Two other important aspects that must be investigated are (i) the effect of technology, as in $\mathrm{N}$ and $\mathrm{P}$ addition during biostimulation and rhizodeposition during phytoremediation, and (ii) the influence of soil components that play critical roles in the bioavailability of the hydrocarbons to the biota.

The limiting concentration required to induce enzyme synthesis and potential product inhibition must also be evaluated. The other possibility is to monitor bioremediation processes using a battery of bioindicators, as attempted by Phillips et al. (2000). The battery must consist of different bioindicators with different sensitivities to hydrocarbon contamination. A 
comparison with uncontaminated soil of identical texture must be made when determining the hydrocarbon toxicity.

In as far as microorganisms are concerned, the use of molecular techniques as potential monitoring tools for characterizing both microbial communities and functional genes during soil remediation needs to be evaluated. Substrate utilization techniques can also be used to evaluate population changes during bioremediation, but their limitations in evaluating most soil microbes present some drawbacks.

It is not well documented that plant sensitivity to toxicants can vary substantially with environmental conditions such as organic matter, $\mathrm{pH}$, ligands and toxicant interactions and whether this sensitivity can vary on a species by species basis.

The extent to which bioindicators respond to non-bioavailable poorly extractable pollutants is not well documented. The effect of non-bioavailable hydrocarbons in soil on enzyme synthesis and seed germination needs to be investigated.

There is still work that must be done on bioindicators before they can be used on their own to monitor hydrocarbon contamination and removal. The recommendations made by Freemark et al. (1990) and Freemark and Boutin (1994) are valid. There is a need to use more relevant ecological test species or activity, existing protocols must be modified/new methods developed, tests need to be standardized and relevant test end points must be selected. At present, it is best that they be used to complement existing conventional monitoring instruments.

\section{Acknowledgements}

The authors would like to thank Drs. K Drønen, (Bergen University, Norway), and P. Wade (Phokus Technologies, SA) for their constructive suggestions.

\section{References}

Adema, D.M.M., Henzen, L., 1989. A comparison of plant toxicities of some industrial chemicals in soil culture and soilless culture. Ecotoxicology and Environmental Safety 18, 219-229.

Athey, L.A., Thomas, J.M., Miller, W.E., Word, J.Q., 1989. Evaluation of bioassays for designing sediment cleanup strategies at a wood treatment site. Environmental Toxicology and Chemistry 8, 223-230.

Bayer, H., Mitterer, M., Schinner, F., 1982. Der Einfluss von Insektiziden auf mikrobiogene Prozesse in Ah-Materialien eines landwirtschaftlich genutzten Bodens. Pedobiologia 23, 311-319.

Belkin, S.M., Stieber, A., Tiehm, F.H., Frimmel, A., Abeliovich, P., Werner, P., Ultizur, S., 1994. Toxicity and genotoxicity enhancement during polycyclic aromatic hydrocarbons biodegradation. Environmental Toxicology and Water Quality 9, 303-309.

Benton, M.J., Malott, M.L., Knight, S.S., Cooper, C.M., Benson, W.H., 1995. Influence of sediment composition on apparent toxicity in a solid phase test using bioluminescent bacteria. Environmental Toxicology and Chemistry 14, 411-414.

Bitton, G., Koopman, B., 1992. Bacterial and enzymatic bioassays for toxicity testing in the environment. Reviews of Environmental Contamination and Toxicology 125, 1-22.

Brock, T.D., Madigan, M.T., 1991. Biology of Microorganisms, 6th ed. Prentice-Hall, New York, pp. 171-175.

Cairns, J., 1993. Environmental science and resource management in the 21 st century: scientific perspective. Environmental Toxicology and Chemistry 12 , $1321-1329$.

Chapman, P.M., 1995. Extrapolating laboratory toxicity results to the field. Environmental Toxicology and Chemistry 14, 927-930.

Cole, D., 1983. Oxidation of xenobiotics in plant. Progress in Pest Biochemistry and Toxicology 3, 199-253.

Cook, N.H., Wells, P.G., 1996. Toxicity of Halifax Harbour sediments: an evaluation of Microtox solid-phase test. Water Quality Research Journal of Canada 31, 673-708.

Curl, E.A., Truelove, B., 1986. Rhizosphere in relation to plant nutrition and growth. In: The Rhizosphere. Springer, Berlin, Germany, pp. $167-189$.

Delistraty, D., 1984. Bioluminiscent toxicity assay of synfuel byproduct waters. Bulletin of Environmental Contamination and Toxicology 32, 613-620.

DeVliegher, W., Verstraete, W., 1996. Formation of non-bioavailable organic residues in soil: perspective for site remediation. Biodegradation 7, 471-485.

Dick, R.P., 1997. Soil enzyme activities as integrative indicators of soil health. In: Panhurst, C.E., Double, B.M., Gupta, V.V. (Eds.), Biological indicators of soil health. Commonwealth Agricultural Bureaux International, Oxford, UK, pp. 121-157.

Dorn, P.B., Vipond, T.E., Salanitro, J.P., Wisniewskie, H.L., 1998. Assessment of the acute toxicity of crude oils in soils using earthworms, microtox, and plants. Chemosphere 37, 845-860.

Dutka, B.J., Teichgraber, K., Lifshitz, R., 1995. A modified SOS-Chromotest procedure to test for genotoxicity and cytotoxicity in sediments directly without extraction, NWRI Contribution No. 95-53. National Water Research Institute, Gatineau, Quebec, Canada.

Erickson, D.C., Loehr, R.C., Neuhauser, E.F., 1993. PAH loss during bioremediation of manufactured gas plant site soils. Water Research 27, 911-919.

Frankenberger, W.T., Johanson, J.B., 1982. Influence of crude oil and refined petroleumproducts on soil dehydrogenase activity. Journal of Environmental Quality 11, 602-607.

Freemark, K., Boutin, C., 1994. Non-target-plant risk assessment for pesticide registration. Environmental Management 18, 841-854.

Freemark, K., MacQuarrie, P., Swanson, S., Peterson, H., 1990. Development of guidelines for testing pesticide toxicity to nontarget plants in Canada. ASTM STP 1091, American Society for Testing and Materials, Philadelphia, PA, pp. 14-29.

Green, J.C., Bartels, C.L., Warren-Hicks, W.J., Parkhurst, B.R., Linder, G.L., Peterson, S.A., Miller, W.E., 1988. Protocols for short term toxicity screening of hazardous waste sites. US EPA Report no. 600/3-88/029. United States Environmental Protection Agency, Washington, DC.

Heitzer, A., Malachowsky, K., Thonnard, J.E., Blenkowski, P.R., White, D.C., Sayler, G.S., 1994. Optical biosensor for environmental on-pine monitoring of naphthalene and salicylate bioavailability with an immobilized bioluminescent catabolic reporter bacterium. Applied and Environmental Microbiology 60, 1487-1494.

Hund, K., Traunspurger, W., 1994. Ecotox-evaluation strategy for soil bioremediation exemplified for a PAH-contaminated site. Chemosphere 29, 371-390. 
Janke, S., Schamber, H., Kunze, C., 1992. Beeinflussung der bodenbiologischen Aktivitat durch Heizol. Angewandte Botanik 66, 42-45.

Kaiser, K., Palabrica, V., 1991. Photobacterium phosphoreum toxicity data index. Water Pollution Research Journal of Canada 26, 361-431.

Kandeler, E., Pennerstorfer, C., Bauer, E., Braun, R., 1994. Microbiological control of the biological decontamination of soils. Zeitschrift fur Pflanzenernahrung und Bodenkunde 157, 345-350.

King, J.M.H., DiGrazia, P.M., Applegate, B., Burlage, B., Sansever-ino, J., Dunbar, P., Larimer, F., Sayler, G., 1990. Rapid, sensitive bioluminescent reporter technology for naphthalene exposure and biodegradation. Science 249, 778-781.

Loehr, R.C., Webster, M.T., 1996. Behaviour of fresh vs. aged chemicals in soil. Journal of Soil Contamination 5, 361-383.

Knoke, K.L., Marwood, T.M., Cassidy, M.B., Liu, D., Seech, A.G., Trevors, J.T., 1999. A comparison of five bioassays to monitor toxicity during bioremediation of pentachlorophenol-contaminated soil. Water, Air and Soil Pollution 110, 157-159.

Kwan, K.K., Dutka, B.J., 1992. Evaluation of toxi-chromotest direct sediment toxicity testing procedure and microtox solid-phase testing procedure. Bulletin of Environmental Contamination and Toxicology 49, 656-662.

Maila, M.P., Cloete, T.E., 2002. Germination of Lepidium sativum as a method to evaluate polycyclic aromatic hydrocarbons (PAHs) removal from contaminated soil. International Biodeterioration and Biodegradation 50, 107-113.

Manilal, V.B., Alexander, M., 1991. Factors affecting the microbial degradation of phenathrene in soils. Applied Microbiology and Biotechnology 35, 401405.

Margesin, R., Schinner, F., 1997. Bioremediation of diesel-oil-contaminated alpine soil at low temperatures. Applied Microbiology and Biotechnology 47, $462-468$.

Margesin, R., Zimmerbauer, A., Schinner, F., 1999. Soil lipase activity—a useful indicator of oil biodegradation. Biotechnology Techniques 13, 859-863.

Margesin, R., Schinner, F., Zimmerbauer, A., 2000. Monitoring of bioremediation by soil biological activities. Chemosphere 40, 339.

Martin, J.P., Parsa, A.A., Haider, K., 1978. Influence of intimate association with humic polymer on biodegradation of ${ }^{14} \mathrm{C}$-labelled organic substances in soil. Soil Biochemistry 10, 483-486.

Marwood, T.M., Knoke, K., Yau, K., Suchorski-Tremblay, A., Fleming, C.A., Hodge, V., Liu, D., Seech, A.G., Lee, H., Trevors, J.T., 1998. Comparison of toxicity detected by five bioassays during bioremediation of diesel-spiked soil. Environmental Toxicology and Water Quality 13, 117-126.

Mueller, J.G., Middaugh, D.P., Lantz, S.E., Chapman, P.J., 1991. Biodegradation of creosote and pentachlorophenol in contaminated groundwater: chemical and biological assessment. Applied and Environmental Microbiology 57, 1277-1285.

Pearce, K., Snyman, H., Heerden, H., Greben, H., Oellermann, R.A., 1995. Bioremediation technology for the treatment of contaminated soil in South Africa, WRC Report No. 543/1/95. Water Research Commission, Pretoria, South Africa.

Phillips, T.M., Liu, D., Seech, A.G., Lee, H., Trevors, J.T., 2000. Monitoring bioremediation in creosote-contaminated soils using chemical analysis and toxicity tests. Journal of Industrial Microbiology and Biotechnology 24, 132-139.

Pokorna, V., 1964. Method of determining the lipolytic activity of upland and lowland peats and muds. Soviet Soil Science 1, 85-87.

Quillardet, P., Hofnung, M., 1993. The SOS chromotest: a review. Mutation Research 297, 235-279.

Ringwood, A.H., DeLorenzo, M.E., Ross, P.E., Holland, A.F., 1997. Interpretation on microtox solid-phase toxicity tests: the effects of sediment composition. Environmental Toxicology and Chemistry 16, 1135-1140.

Schinner, F., Ohlinger, R., Kandeler, E., Margesin, R. (Eds.), 1996. Methods in Soil Biology. Springer, Heidelberg, pp. $204-207$.

Shakir, H., Safwat, H., Weaver, R.W., 2002. Earthworm survival in oil contaminated soil. Plant and Soil 240, 127-132.

Siciliano, S.D., Germida, J.J., Headley, J.V., 1997. Evaluation of prairie grass species as bioindicators of halogenated aromatics in soil. Environmental Toxicology and Chemistry 16, 521-527.

Sims, G.K., Radosevich, M., He, X.T., Traina, S.J., 1991. The effects of sorption on the bioavailability of pesticides. In: Betts, W.B. (Ed.), Biodegradation: Natural and Synthetic Materials. Springer, Berlin, pp. 120-137.

Steinberg, S.M., Poziomek, E.J., Englemann, W.H., Rogers, K.R., 1995. A review of environmental applications of bioluminescent measurements. Chemosphere 30, 2155-2197.

Stevenson, I.L., 1959. Dehydrogenase activity in soils. Canadian Journal of Microbiology 5, 229-235.

Top, E.M., Maila, M.P., Clerinx, M., Goris, J., De Vos, P., Verstraete, W., 1999. Methane oxidation as method to evaluate the removal of 2,4-D from soil by plasmid-mediated bioaugumentation. FEMS Microbiology Ecology 28, 203-213.

Van Beelen, P., Doelman, P., 1997. Significance and application of microbial toxicity tests in assessing ecotoxicological risks of contaminants in soil and sediments. Chemosphere 34, 455-499.

Van der Waarde, J.J., Dijkhuis, E.J., Henssen, M.J.C., Keuning, S., 1995. In: Hinchee, R.E., Douglas, G.S., Ong, S.K. (Eds.), Monitoring and Verification of Bioremediation. Battelle Press, Columbus, OH, pp. 59-63.

Van Veen, J.A., Van Overbeek, L.S., Van Elsas, J.D., 1997. Fate and activity of microorganisms introduced into soil. Microbiology and Molecular Biology Reviews 61, 121-135.

Wang, W., Freemark, K., 1995. The use of plants for environmental monitoring and assessment. Ecotoxicology and Environmental Safety 30, $289-301$.

Weissenfels, W.D., Beyer, M., Klein, J., 1992. Adsorption of polycyclic aromatic hydrocarbons (PAHs) by soil particles: influence on biodegradability and biotoxicity. Applied Microbiology and Biotechnology 35, 689-696.

White, J.C., Alexander, M., 1996. Reduced biodegradability of desorption resistant fractions of poly aromatic hydrocarbons in soil and aquifer solids. Environmental Toxicology and Chemistry 15, 1973-1978.

Wünsche, L., Brüggemann, L., Babel, W., 1995. Determination os substrate utilization patterns of soil microbial communities: an approach to assess population changes after hydrocarbon pollution. FEMS Microbiology Ecology 17, 295-306. 